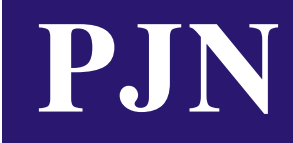

ISSN 1680-5194

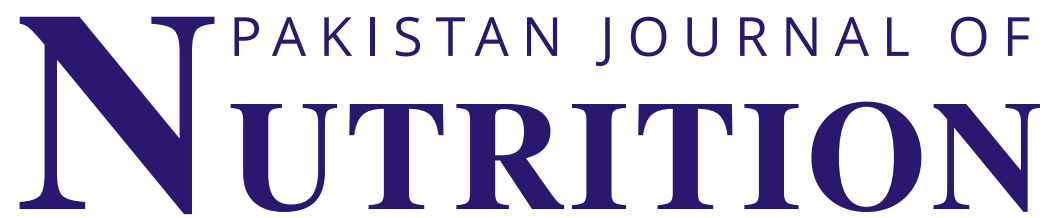

ANSI迫e佔

308 Lasani Town, Sargodha Road, Faisalabad - Pakistan Mob: +92 3003008585 , Fax: +92 418815544

E-mail: editorpjn@gmail.com 
Pakistan Journal of Nutrition 3 (4): 237-239, 2004

(C) Asian Network for Scientific Information, 2004

\title{
Effect of Protein Supplementation on Growth Performance in Female Goats and Sheep under Grazing Condition
}

\author{
F. Kabir ${ }^{1}$, M.S. Sultana ${ }^{2}$, M. Shahjalal ${ }^{2}$, M.J. Khan² and M.Z. Alam ${ }^{1}$ \\ ${ }^{1}$ Barisal Government Veterinary College, Khanpura, Babugonj, Barisal, Bangladesh \\ ${ }^{2}$ Bangladesh Agricultural University, Mymensingh- 2202, Bangladesh \\ E-mail: kabirfaisal@yahoo.com
}

\begin{abstract}
The experiment was conducted to determine the effect of protein supplementation on growth performance in female goats and sheep. Ten does and six ewes aged about 15 months and weighing on average, 13.9 and $14.4 \mathrm{~kg}$ respectively were studied in this experiment. Animals were allocated to two feeding regimes [low protein (LP), $168 \mathrm{~g}$ and high protein (HP), $208 \mathrm{~g}$ per $\mathrm{kg} \mathrm{DM}$ ] in a randomized block design according to live weight. HP diet did not significantly $(p>0.05)$ increase live weight gain (33.0 vs. 25.2 $\mathrm{g} / \mathrm{d})$ in goats. In contrast, sheep received the HP diet significantly $(p<0.05, p<0.01)$ improved DM intake $(509.0$ vs. $425.9 \mathrm{~g} / \mathrm{d})$ and live weight gain ( $36.6 \mathrm{vs} .10 .7 \mathrm{~g} / \mathrm{d}$ ) compared to those given the LP diet. These results indicate that supplementary feeding of high protein diet (208g CP per $\mathrm{kg}$ DM) significantly increased growth performance of sheep under grazing condition.
\end{abstract}

Key words: Goat, sheep, protein supplement, growth

\section{Introduction}

Livestock play an important role in the national economy. Among domestic animals, goats and sheep play a significant role in the subsistence economy of Bangladesh. More than 80 per cent of goats and sheep in Bangladesh are found in villages, where they are generally raised by poor farmers and distressed women with very little capital inputs (FAO, 1991). According to BBS (1990) goats are reared by the small, marginal and landless farmers $(55 \%)$ followed by medium $(35 \%)$ and large farmers (10\%). They are reared mostly in village situation in the subsistence level and lived to survive in various nutritional and environmental condition (Devendra and Burns, 1970). Goats and sheep are multipurpose animals, which provide meat, milk, hair, wool and skin. The country has 35.6 million goats and sheep representing $58.8 \%$ (96.7\% goat alone) of total livestock population and yielding 119 thousand metric tons $(97.5 \%$ goat meat) of meat annually, which accounts for $28.7 \%$ of total livestock meat (FAO, 1997). The production of meat from goats and sheep, play an important role to supply animal protein for the people of our country. Goat meat is one of the most commonly eaten red meat and highly acceptable to people of all castes and religion. The genetic potentiality and productivity of goats and sheep are deteriorating day by day due to indiscriminate breeding, lack of improved feeding and poor management practices. Goat production in the villages by traditional husbandry system is often characterized by poor growth rates, high mortality and low reproductive rates. In this situation, the productivity of goat may be increased by controlling diseases through vaccination and anthelmintic drug and improving nutrition by either concentrate feeding or supply additional forage. Sheep can also be maintained easily under rural conditions because of their ability to adapt in harsh environment, poor management and less feed consumption. Most of the farmers rear their goats and sheep in extensive system in ranged condition without any supplementation. This system of production causes reduced growth rate and poor reproductive performance, which in turn results in severe economic loss. Some previous studies (Kochapakdee et al., 1994) have reflected the importance of concentrate supplementation on growth and productivity of goats and sheep. These authors also reported that grazing alone may not be sufficient for optimizing live weight gain and wool production. If scavenging type of rearing can be supplemented with minimum amount of protein rich concentrate then the level of production may be increased at the minimum cost. The present experiment was designed to determine the effect of supplementation of dietary protein on growth performance of female goats and sheep raised under grazing condition.

\section{Materials and Methods}

The experiment was conducted at Bangladesh Agricultural University, Mymensingh, Bangladesh, during the period of 1999 to 2000 .

Animals, diets and experimental design: Ten (10) does and six (6) ewes aged about fifteen months and weighing on average 13.9 and $14.4 \mathrm{~kg}$ respectively were used in this experiment. The animals were ear tagged and allowed 7-days to adapt to the experimental conditions prior to the commencement of the study. Feces of each goats and sheep was examined for 
Kabir et al.: Effect of Protein Supplementation on Goats and Sheep

Table 1: Effect of protein supplementation on growth performance of goats and sheep

\begin{tabular}{|c|c|c|c|c|c|c|c|c|}
\hline \multirow[t]{2}{*}{ Parameter } & \multicolumn{2}{|l|}{ Goats } & \multirow[t]{2}{*}{ SEM } & \multirow{2}{*}{$\begin{array}{l}\text { Level of } \\
\text { Signifi- } \\
\text { cance }\end{array}$} & \multicolumn{2}{|l|}{ Sheep } & \multirow[t]{2}{*}{ SEM } & \multirow{2}{*}{$\begin{array}{l}\text { Level of } \\
\text { Signifi- } \\
\text { cance }\end{array}$} \\
\hline & LP & $\mathrm{HP}$ & & & LP & $\mathrm{HP}$ & & \\
\hline Initial live weight (kg) & 13.86 & 14.00 & 0.56 & NS & 14.27 & 14.57 & 1.06 & NS \\
\hline Final live weight $(\mathrm{kg})$ & 16.68 & 17.70 & 0.83 & NS & 15.47 & 18.67 & 0.88 & NS \\
\hline Total live weight gain $(\mathrm{kg})$ & 2.82 & 3.70 & 0.51 & NS & 1.20 & 4.10 & 0.18 & ** \\
\hline Average live weight gain $(\mathrm{g} / \mathrm{d})$ & 25.18 & 33.03 & 4.51 & NS & 10.71 & 36.61 & 1.59 & ** \\
\hline \multicolumn{9}{|l|}{ Total dry matter (DM) } \\
\hline intake $(\mathrm{kg})$ & 52.98 & 51.73 & 2.18 & NS & 47.70 & 57.01 & 0.70 & * \\
\hline DM intake (g/d) & 473.00 & 461.90 & 19.45 & NS & 425.90 & 509.00 & 6.26 & * \\
\hline DM intake (\% live weight) & 3.23 & 3.07 & 0.26 & NS & 2.97 & 3.08 & 0.19 & NS \\
\hline DM intake $\left(\mathrm{g} / \mathrm{kg}^{0.75} / \mathrm{d}\right.$ & 62.98 & 60.20 & 4.37 & NS & 57.51 & 62.02 & 2.58 & NS \\
\hline Feed conversion efficiency (DMl/LWG) & 20.40 & 15.82 & 4.34 & NS & 35.17 & 13.93 & 4.08 & NS \\
\hline Crude protein intake $(\mathrm{g} / \mathrm{d})$ & 59.91 & 73.14 & 1.96 & ** & 55.39 & 78.54 & 0.59 & ** \\
\hline Protein conversion efficiency (CPI/LWG) & 2.58 & 2.51 & 0.55 & NS & 4.58 & 2.15 & 0.55 & NS \\
\hline
\end{tabular}

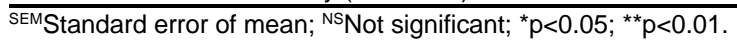

parasitic infestation and all the animals were dewormed with an anthelmintic drug. Based on live weight, does were blocked into five (5) groups and ewes were blocked into three (3) groups. The animals (goats and sheep) in each block were then allocated at random to two supplementary diets containing low protein (LP) and high protein (HP). Goats and sheep were allowed to graze 06:00 hours daily during day. Moreover, animals in each group were received either a high protein (HP) diet $(300 \mathrm{~g} / \mathrm{d})$ consisting of wheat bran $(35 \%)$, rice polish $(35 \%)$ and soybean meal (30\%) or low protein (LP) diet $(300 \mathrm{~g} / \mathrm{d})$ consisting of wheat bran $(43 \%)$, rice polish $(43 \%)$ and soybean meal (14\%). The supplemental diets contained $208 \mathrm{~g}$ (HP) and 168g (LP) CP per kg dry matter (DM). The supplemental diets were supplied daily at night, when animals were kept in individual pen. All the animals were reared under the same management.

Measurements and procedures: Dry matter (DM) and nutrients intake by goats and sheep were estimated by measuring the refusals of feed. In addition to grazing, each species of animals (goats and sheep) were allowed to fed a concentrate diet containing two different levels of protein, when they were housed in individual pen at night. In every morning, feed refusals were collected and then weighed to determine the daily feed intake of each animal. Goats and sheep were initially weighed and then every 7-day interval throughout the experimental period. The animals were weighed at 07:30 hours prior to allowing them for grazing. At the end of the experimental period, the average weight of individual animal was also recorded.

Statistical analysis: The experimental data on growth performance and dry matter intake of goats and sheep were analyzed (ANOVA) following Randomized Block Design (RBD).

\section{Results and Discussion}

Growth performance of goats and sheep: The effect of protein supplementation on intake and growth performance of goats and sheep is shown in Table 1. Feeding of goats with high protein (HP) diet significantly $(p<0.01)$ increased crude protein intake (73.14 vs. 59.91 $\mathrm{g} / \mathrm{d}$ ) compared with low protein (LP) diet. However, no significant $(p>0.05)$ difference was observed between the LP and HP diet for the values of DM intake and live weight gain although there was a tendency to increase live weight gain in goats given the HP diet. Shahjalal et al. (1997) reported that growth rate of grazing Black Bengal goats can improved under conditions of increased protein supplementation. Feeding of sheep with HP diet significantly $(p<0.01, p<0.05)$ increased CP intake (78.54 vs. $55.39 \mathrm{~g} / \mathrm{d}$ ) and DM intake (509.0 vs. $425.9 \mathrm{~g} / \mathrm{d}$ ) compared with those received the LP diet. This protein intake resulted in increased $(p<0.01)$ live weight gain in sheep received the HP diet. Ranhotra and Jordan (1966) observed that lambs gained faster during the $1^{\text {st }} 28$ days after weaning when given $12 \%$ protein or more. DM intake was also influenced significantly $(p<0.05)$ by dietary CP level. This can be related with the findings of Lu and Potchoiba (1990) who suggested that DM intake in goats increased linearly as dietary CP level increased. The results suggest that the effect of supplementing high protein on intake and live weight gain was higher in sheep than goats.

\section{References}

BBS (Bangladesh Bureau of Statistics), 1990. Statistical Pocket Book of Bangladesh. Statistics Division, Ministry of Planning Dhaka, Bangladesh.

Devendra, C. and M. Burns, 1970. Goat Production in the Tropics. Tech. Commun. No. 19. Comm. Agric. Bur., Farnham Royal, England, 12: 184.

FAO (Food and Agriculture Organization of the United Nations), 1991. Asian Livestock. Monthly Technical Magazine of the FAO Animal Production and Health Commission for Asia and the Pacific (APHCA), (16)8: 85-87.

FAO (Food and Agriculture Organization of the United Nations), 1997. Production Year Book, Rome, Italy, 51: 189-228. 
Kabir et al.: Effect of Protein Supplementation on Goats and Sheep

Kochapakdee, S., W. Pralomkarn, S. Saithanoo, A. Lawpetchara and B.W. Norton, 1994. Grazing management studies with Thai goats: 1 . Productivity of female goats grazing newly established pasture with varying levels of supplementary feeding. AsianAus. J. Anim. Sci., 7: 289-293.

Lu, C.D. and M.J. Potchoiba, 1990. Feed intake and weight gain of growing goats fed diets of various energy and protein levels. J. Anim. Sci., 68: 17511759 .
Ranhotra, G.S. and R.M. Jordan, 1966. Protein and energy requirements of lambs weaned at 6 to 8 weeks of age as determined by growth digestion studies. J. Anim. Sci., 25: 630-635.

Shahjalal, M., M.A.A. Biswas and A.M.M. Tareque, 1997. Effect of feeding Sesbania leaves on growth and nutrient utilization in goats. Bang. J. Anim. Sci., 26: 117-123. 